\title{
An Assessment of Compliance with The European and National Minimum Requirements on Calf Welfare of Dairy Cattle Farms in İzmir Province
}

\author{
Zehra BOZKURT ${ }^{1 *}$, Mustafa MUTLU ${ }^{2}$ \\ ${ }_{1}$ Afyon Kocatepe University, Faculty of Veterinary Medicine, Department of Animal Husbadry, 03200, Afyonkarahisar \\ ${ }^{2}$ Ministry of Agriculture and Forestry, Baynder Agriculture District Directorate, Bayınder, İzmir
}

\begin{abstract}
The aim of this study was to assess the compliance of dairy cattle farms in Izmir with the minimum requirements for calf welfare. The research was carried out in 30 dairy cattle farms in Bayındir district of Izmir province. A measurement, observation and evaluation form was used that developed based on the minimum calf welfare requirements defined in the European Union (2008/119/EC) and national animal welfare legislation. Observations, determinations and measurements were made in the dairy cattle farms that accepted to participate in this research, and resource and management based welfare assessments were performed in calf barns. According to the findings, the physical conditions for feeding and housing of calves were favourable; however, cleanliness of barns and equipments and use of bedding were poor. As a result, it was determined that minimum requirements for calf welfare in dairy cattle farms in Bayındır district in İzmir province were met in terms of feeding, health care and daily inspection, but there were significant shortcomings related to good housing. To raise awareness of animal welfare and increasing the level of education of farmers on the concept and legislation of animal welfare has been proposed in order to increase dairy farms' compliance with calf welfare requirements. Keywords: İzmir Province, Dairy Cattle Farms, Welfare standards, Calf Welfare
\end{abstract}

\section{İzmir İlindeki Süt Sığırı İşletmelerinin Buzağı Refahı Bakımından Avrupa Birliği ve Ulusal Minimum Gerekliliklere Uyumunun Değerlendirilmesi}

\section{ÖZ}

$\mathrm{Bu}$ araştırmanın amacı, İzmir ilinde bulunan süt sığırı işletmelerinin minimum buzağı refahı gerekliliklerine uyumunun değerlendirilmesidir. Araştırma, İzmir iline bağlı Bayındır ilçesinde toplam 30 süt sığırı işletmesinde yürütülmüş̧ür. Avrupa Birliği (2008/119/EC) ve ulusal mevzuatta tanımlanan asgari buzağı refahı gerekliliklerine dayanılarak geliştirilen bir ölçme, gözlem ve değerlendirme formu kullanılmıştır. Araştırmaya katılmayı kabul eden çiftliklerde gözlem, tespit ve ölçümler yapılarak buzağı barınaklarında kaynak ve idare ile ilgili refah değerlendirmeleri yapılmıştır. Elde edilen bulgulara göre, buzağıların beslenme ve barınmasına ilişkin fiziki koşulların uygun olduğu ancak barınak ve ekipman temizliği ile altlık kullanımının yetersiz olduğu tespit edilmiştir. Sonuç olarak, İzmir'in Bayındır ilçesinde süt sı̆̆ırı işletmelerinde buzağı refahı yönünden minimum gerekliliklerin besleme, sağlık idaresi ve günlük kontroller açısından karşılandığı, ancak barındırma ile ilgili önemli eksikliklerin bulunduğu belirlenmiştir. Süt sığırı işletmelerinin buzağı refahı minimum gerekliliklerine uyumunun arttırlması için çiftçilerin hayvan refahı kavramı ve mevzuatı konusunda farkındalığının ve eğitim düzeyinin arttırılması önerilmiştir.

Anahtar Kelimeler: İzmir İli, Süt Sığırı İşletmeleri, Refah Standartları, Buzağ1 Refahı

To cite this article: Bozkurt Z. Mutlu M. An Assessment of Compliance with The European and National Minimum Requirements on Calf Welfare of Dairy Cattle Farms in İmir Province. Kocatepe Vet J. (2019) 12(4):448-455. 


\section{INTRODUCTION}

It is expected to that worldwide demand for animal products such as meat and milk will increase in the coming years (Berckmans 2014). In order to correspond to the increase in food demand, intensive animal production techniques and feed technologies are used in farms and, the management of dairy cattle herds includes more and more automation (Smil 2002, Miller et al. 2010, Berckmans 2014).

With the pressure of high genetic selection, highyielding cows were subjected to stressful intensive farm conditions. So, they have been managed with herd management strategies and mass production approaches (Webster, 2019). These production strategies also affect to calves (Beam et al. 2009). Recently, increasing consumer concern about animal welfare, food quality and safety and environmental protection led to a revision of intensive animal production strategies (Blokhuis et al. 2003, Webster 2019). World Animal Health Organization was announced that, if animals are healthy and relaxed, feed well, exhibit their innate behaviours, and if they do not suffer from pain, fear or discomfort, their well-being is good (OIE 2012). These are related to three dimentions of animal welfare concept such as; animal's normal biological functions work without difficulty (healthy, feed well, etc.), animal's emotional state is positive (absence of negative emotions such as pain and chronic fear), and animals can exhibit certain normal behaviours (Blokhuis et al. 2003, Berckmans 2014, Webster 2019).

The EU published the White Paper and carried out fundamental reforms in the area of food safety and quality in the year 2000. This reforms of the Union include an effective consumer policy with an update of current legislation, strengthened management and traceability in food production (Blanchard 2004). Thus, the "farm-to-fork" food safety approach was implemented aiming to take of public health and animal health at the center of EU food policy instead of a production-oriented approach (EFSA 2015). The European Union Animal Welfare Strategy 2012-2015 purposes to simplify the animal welfare regulations in the Union and to strengthen the competitiveness of agriculture by increasing the synergy in the Common Agricultural Policy (Main at al. 2014). In order to increase the competitiveness of the member countries in the global food market, European Union's food chain policy is focused on the links between animal welfare, animal health and food safety. Turkey will also comply with these European policies as a candidate country for accession to EU.

Turkey's accession negotiations for full membership to EU were started in 2005 and within the scope of the acquis studies (for 12. Food Safety, Veterinary and Phytosanitary Policy chapter), the Implementing
Regulation on Minimum Standards for the Protection of Calves entered into force 22 November of 2014 (Official Gazette No: 29183) and it has defined the legal minimum requirements for protection of calves on the dairy cattle farms in Turkey (comply with 2008/119/EC). According to this legislation, animal welfare inspections have to be carried out in dairy cattle farms annualy (EU 2009, Anonymous 2014). Therefore, the compliance of dairy cattle farms with EU and National welfare legislation is significant to improve the competitiveness of Turkey's milk sector in Union (Anonymous 2018).

This study was conducted to assess the compliance of dairy cattle farms with minimum legal requirements for calf welfare in Izmir that is the second largest cow milk producer province in Turkey.

\section{MATERIAL and METHOD}

\section{Development of the measurement, observation and evaluation form}

The study was performed in a total 30 dairy cattle farms consisting of small (1-50 cows), medium (51100 cows) and large (101 cows and more) sized farms in 8 central villages in Bayındır district of İzmir province during May and June in 2018. The dairy cattle farms were randomly selected with the stratified and cluster sampling methods. After interviewed with the farm owners and explained our research to them the farms were visited that agreed to participate in the research (same numbers of farms from each farm size group were surveyed).

A measurement, observation and evaluation form has been developed for use in this study. This form was depended on the minimum calf welfare requirements defined by the EU (Directive 2008/119/EU) and national legislation (Regulation on Minimum Standards for the Protection of Calves) (EU 2009, Anonymous 2014). In addition that, Welfare Quality ${ }^{\circledR}$ protocol which have been developed to assessment of calf welfare were used (Welfare Quality 2009). The form consisted of two sections. The first section was included the qualitative and quantitative observations and measurements on calf rearing to be used for resource-based assessments of calf welfare (properties of barns or pens, equipments, feed and water resources, air conditioning, ventilation, lighting). In order to be used for management-based assessments of calf welfare, the second section was covered the calf rearing practices and the farm data were obtained from the farmers by face to face interviews or farm data were received from farms where records were kept regularly (painful or aversive treatments, calf feeding with colostrum or milk, bedding, calf rearing management, ect). All measurements, observations and evaluations and face-to-face interviews within each farm were made 
by the same person and completed within the same day.

The following observations, evaluations and measurements were carried out to asses the accommodation confort and easy movement possibility of animals in the barns; pen types (individual or group), numbers of pens and total floor areas of each pens, usage harmfull materials to calves in the construction of calf barns (present or not present), presence of appropriate insulation, heating and ventilation devices, ventilation type (natural, mechanical, natural supporting mechanical system are mixed), presence appropriate natural or artificial lighting equipment (present or not present), calf housing density in group pens( floor area per calf), floor slipperiness and cleanless of barns and providing of appropriate bedding in the calf in rest areas (present, present but insufficient, not present sufficiently).

In terms of good health principle, the questions were asked to the farmes; whether the sick calves were isolated in adequate accommodation with dry, comfortable bedding, frequency of ispection of calves' health and well-being in a day, provision of veterinary care for all sick calves, the number of dead calves (lossed) in last 12 months and the surgical procedures or modifications in calves (castration, procedures for tail docking and disbudding or dehorning).

The observations and examinations to evaluate of calf welfare in line to good feeding principle were the types of calf feeders and water points (individual or group) or feeding systems (manual or automatic), cleanness and functioning of feeding devices, the way of calf feeding with colostrum, milk or replacers (bottle or mother sucking), the possibility of reach to food of all calves at the same time when using automatic feeding systems in group barns and adequate composition of replacers especially for iron and fibrous food. Farmers were asked whether colostrum was given to calves in the first 6 hours after birth, duration of each colostrum meal, daily milk feeding frequency, management of milk feeding program up to weaning, weaning age and weaning method. It was observed whether there was generator in the farm and whether the mechanical and automatic equipment is combined with an alarm. The alternative feeding and ventilation methods and frequency of control of the automatic equipment were learned from the farmers. Tethered calves in the visited farms were counted.

The statical analysis was performed using SPSS 18.01 for Windows and Microsoft Excel 2007 programs. The descriptive statistics (percentages, means and standard error of mean) were used in the analysis of the data to determine the present situation in terms of compliance with the minimum calf welfare requirements on dairy farms.

\section{RESULTS}

The results on the resource-based and managementbased animal welfare assessments for dairy calf welfare related to housing and automatic equipment management in the farms are shown in Table 1 . Most of pens that were observed in the farms $(63.33 \%)$ were group pens. It was determined that $80.00 \%$ of the dairy farms did not use any materials that could be harmful to the well-being and health of calves in the construction of calf barns. The bedding was favourable in calf resting areas in $3.40 \%$ of the farms. However, calf pen's floor were not slippery in $96.70 \%$ of the farms. Only $40.00 \%$ of the farms had clean calf pens and disinfection frequency was sufficient in this areas. Insulation, heating and ventilation of animal barns were suitable in $73.30 \%$ and installation of electrical circuits and equipment was appropriate all of the farms and there were lighting equipments to provide adequate natural and/or artificial light in $73.30 \%$ of farms. In the visited dairy farms, the average number of individual and group pens were of 6.73 and 2.75 and total floor area of those pens were 3.96 and $32.22 \mathrm{~m}^{2}$ respectively. The mean housing density was found as $4.33 \mathrm{~m}^{2} /$ calf in group pens (Table 1).

In $3.30 \%$ of the farms automatic feeding and ventilation systems and spare equipments were used, the automatic systems were combined with alarm and checked at least once a day. In all visited farms, it was observed that electrical equipment was placed in a way that would not give electric shocks to calves, but the raito of farms with generator was only $10.00 \%$ (Table 1).

The results on the resource-based and managementbased animal welfare assessment for dairy calves related to feeding, weaning, tethering and health care in dairy cattle farms are presents in Table 2. The ratios of the farms where individual feeders, group feeders and both of two type feeders have been detected as 3.30, 63.30 and $33.40 \%$ respectively. The cleanliness of the feeding systems was insufficient in $36.70 \%$ of the farms. It was observed that the calves were able to take colostrum in the first 6 hours immediately after birth and that colostrum was given to calf by bottle in $96.67 \%$ of the farms. Milk or milk replacers were given to the calves with manuel $(93.37 \%)$ or automatic $(3.33 \%)$ up to weaning age. It was reported that calves were fed twice a day with raw cow milk $(83.30 \%$ of farms) or milk replacers (16.70\% of farms). There were no regular monitoring or data recoding with regard to duration of each colostrum feeding session (Table 2). 
All calves were provided access to food at same time in the farms where automatic feeding was applied and calves are housed in groups. Approximately half of dairy farms $(56.70 \%)$ consider the age of the calf as a criterion for weaning and other half take into account the weight of the calf or the amount of concentrate feed consumed daily. The average age of weaning was calculated as 85.33 days by using the the owners' notifications. Tethered calves were found in $30.00 \%$ of the farms (Table 2).

In the last 12 months, the average number of calves born on dairy farms was calculated as 29.90 . The ratio of the dairy farms that provide adequate accommodation with dry, clean and comfortable bedding for sick calves was only $12.90 \%$ however, all farmers reported that they provides veterinary care when calves get sick and they inspects calves for their health and well-being twice a day. Male calves were vaccinated for pox and mouth disease (FMD), female calves were vaccinated for pox, mouth disease (FMD) and brucellosis, and all calves were identified within 20 days of birth by ear tag. Depending on farmers' reports, the avarage calf mortality was $11.44 \%$ in the last 12 months and only $20.00 \%$ of farms there were no calf losses.As the farmers's declerations, tail docking or castration were not applied but disbudding was performed to calves $(90.00 \%)$ without anesthesia in $86.67 \%$ of the farms (Table 2).

Table 1. The results of assessment of housing and automatic equipment management in terms of their impacts on calf welfare in dairy cow farms.

\begin{tabular}{|c|c|c|c|}
\hline Welfare Principles & \multicolumn{2}{|c|}{$\begin{array}{l}\text { Legal minimum requirements for } \\
\text { protection of calves }\end{array}$} & Results \\
\hline \multirow[t]{19}{*}{ Housing } & \multicolumn{2}{|c|}{ Calf barn types } & $\begin{array}{l}\text { Individual pens }(6.67 \%) \text {, group pens } \\
(63.33 \%) \text {, individual and group calf pens } \\
\text { mixed }(30.00 \%)\end{array}$ \\
\hline & \multirow{3}{*}{\multicolumn{2}{|c|}{$\begin{array}{l}\text { Harmful effects of barn materials } \\
\text { Floor slipperiness } \\
\text { Calf bedding }\end{array}$}} & Present $(20.00 \%)$, not present $(80.00 \%)$ \\
\hline & & & Slippery $(3.30 \%)$, not slippery $) 96.70 \%$ ) \\
\hline & & & $\begin{array}{l}\text { Not present }(73.30 \%) \text {, present but } \\
\text { insufficient }(23.30 \%) \text {, present } \\
\text { suffeciently }(3.40 \%)\end{array}$ \\
\hline & \multirow{3}{*}{\multicolumn{2}{|c|}{$\begin{array}{l}\text { Disinfection frequency of equipments and } \\
\text { cleanliness of barns and pens } \\
\text { Insulation, heating and ventilation } \\
\text { Ventilation type }\end{array}$}} & $\begin{array}{l}\text { Sufficient } \quad(40.00 \%), \quad \text { insufficient } \\
(60.00 \%)\end{array}$ \\
\hline & & & Suitable $(73.30 \%)$, not suitable $(26.70 \%)$ \\
\hline & & & $\begin{array}{l}\text { Natural }(83.30 \%) \text {, mechanical }(3.30 \%) \text {, } \\
\text { natural+ mechanical }(13.40 \%)\end{array}$ \\
\hline & \multirow{2}{*}{\multicolumn{2}{|c|}{$\begin{array}{l}\text { Natural or artificial lighting } \\
\text { Installation of electrical equipment }\end{array}$}} & Present $(73.30 \%)$ not present $(26.70 \%)$ \\
\hline & & & $\begin{array}{l}\text { Does'nt give electric shocks to calves } \\
(100.00 \%)\end{array}$ \\
\hline & \multirow{5}{*}{$\begin{array}{l}\text { Individual } \\
\text { pens }\end{array}$} & Number of individual pens & $6.73 \pm 1.74$ \\
\hline & & Pen lenght $(\mathrm{m})$ & $2.31 \pm 0.32$ \\
\hline & & Pen width (m) & $1.57 \pm 0.12$ \\
\hline & & Total floor area of pen $\left(\mathrm{m}^{2}\right)$ & $3.96 \pm 0.33$ \\
\hline & & $\begin{array}{l}\text { Confinement time in } \\
\text { individual pens (days) }\end{array}$ & $86.11 \pm 2.97$ \\
\hline & \multirow[t]{5}{*}{ Group pens } & Number of group pens & $2.75 \pm 0.29$ \\
\hline & & $\begin{array}{l}\text { Number of calves keep in } \\
\text { group pens }\end{array}$ & $7.14 \pm 0.59$ \\
\hline & & $\begin{array}{l}\text { Total floor area of grup } \\
\text { pen }\left(\mathrm{m}^{2}\right)\end{array}$ & $32.22 \pm 3.33$ \\
\hline & & $\begin{array}{l}\text { Living area per calf in group } \\
\text { pens }\left(\mathrm{m}^{2} / \text { calf }\right)\end{array}$ & $4.33 \pm 0.21$ \\
\hline & & Number of tethered calves & $3.78 \pm 1.06$ \\
\hline \multirow{4}{*}{$\begin{array}{l}\text { Automatic } \\
\text { equipment } \\
\text { management }\end{array}$} & \multirow{2}{*}{\multicolumn{2}{|c|}{$\begin{array}{l}\text { Alarm for mechanical equipment } \\
\text { Daily control for automatic systems }\end{array}$}} & Present $(3.30 \%)$, not present $(96.7 \%)$ \\
\hline & & & Once a day $(100$. \\
\hline & \multirow{2}{*}{\multicolumn{2}{|c|}{$\begin{array}{l}\text { Alternatives for automatic systems } \\
\text { Province of generator }\end{array}$}} & Present $(3.30 \%)$ not present $(96.70 \%)$ \\
\hline & & & Present $(10.00 \%)$ not present $(90.00 \%)$ \\
\hline
\end{tabular}


Table 2. The results of assessment of feeding, weaning, tethering and health care in terms of their impacts on calf welfare in dairy cow farms.

\begin{tabular}{|c|c|c|c|}
\hline Welfare Principles & \multicolumn{2}{|c|}{$\begin{array}{l}\text { Legal minimum requirements for } \\
\text { protection of calves }\end{array}$} & Results \\
\hline \multirow[t]{11}{*}{ Feeding } & \multicolumn{2}{|c|}{ Feeding systems } & Manuel $(96.70 \%)$,automatic $(3.30 \%)$ \\
\hline & \multicolumn{2}{|c|}{$\begin{array}{l}\text { Access to the food at same time in } \\
\text { group housing }\end{array}$} & $\begin{array}{l}\text { Provided for all calves are housed in } \\
\text { groups. }\end{array}$ \\
\hline & \multicolumn{2}{|c|}{ Types of feeders and water points } & $\begin{array}{l}\text { Individual }(3.30 \%) \text {, group }(63.30 \%) \text {, } \\
\text { both of them mixed }(33.40 \%)\end{array}$ \\
\hline & \multicolumn{2}{|c|}{$\begin{array}{l}\text { Cleanliness and functioning of feedings } \\
\text { system }\end{array}$} & $\begin{array}{l}\text { Suitable }(63.30 \%) \text {, not suitable } \\
(36.70 \%)\end{array}$ \\
\hline & \multicolumn{2}{|c|}{$\begin{array}{l}\text { Colostrum feeding immediately after } \\
\text { birth }\end{array}$} & $\begin{array}{l}\text { Within the first } 6 \text { hours the latest } \\
(100.00 \%)\end{array}$ \\
\hline & \multicolumn{2}{|c|}{$\begin{array}{l}\text { Duration of each colostrum feeding } \\
\text { session }\end{array}$} & There were no regular monitoring \\
\hline & \multicolumn{2}{|c|}{ The way of colostrum feeding } & $\begin{array}{l}\text { Bottle suckling }(96.67 \%) \text {, cow suckling } \\
(3.33 \%)\end{array}$ \\
\hline & \multicolumn{2}{|c|}{ Suckling methods } & $\begin{array}{l}\text { Manuel (bottles) (93.37\%), automatic } \\
\text { (multi-nipples pails ) }(3.33 \%)\end{array}$ \\
\hline & \multicolumn{2}{|c|}{$\begin{array}{l}\text { Calf feeding between } 3 \text {-days to } \\
\text { weaning }\end{array}$} & $\begin{array}{l}\text { Raw cow milk }(83.30 \%) \text {, milk replacers } \\
(16.70 \%)\end{array}$ \\
\hline & \multirow{2}{*}{\multicolumn{2}{|c|}{$\begin{array}{l}\text { Feeding or suckling frequency } \\
\text { Calf feed formulation (iron, forage, } \\
\text { etc) }\end{array}$}} & Twice a day $(100.00 \%)$ \\
\hline & & & Appropriate $(100.00 \%)$ \\
\hline \multirow[t]{2}{*}{ Weaning } & \multicolumn{2}{|c|}{ Weaning criteria } & $\begin{array}{l}\text { Calf age }(56.70 \%) \text {, live weight of calf } \\
(20.00 \%) \text { amount of feed } \\
\text { intake }(23.30 \%)\end{array}$ \\
\hline & \multicolumn{2}{|c|}{ Weaning age (days) } & $85.33 \pm 1.83$ \\
\hline Tethering & \multicolumn{2}{|c|}{ Ratio of farms with tethered calves } & Present $(30.00 \%)$, not present $(70.00 \%)$ \\
\hline \multirow[t]{13}{*}{ Health care } & \multicolumn{2}{|c|}{$\begin{array}{l}\text { Adequate accommodation for sick } \\
\text { calves }\end{array}$} & Present $(12.90 \%)$, not present $(87.10 \%)$ \\
\hline & \multicolumn{2}{|c|}{ Veterinary care } & Yes $(100,00 \%)$ \\
\hline & \multicolumn{2}{|c|}{ Daily inspection frequency of the calves } & Twice a day $(100.00 \%)$ \\
\hline & \multicolumn{2}{|c|}{$\begin{array}{l}\text { Vaccination for male calves } \\
\text { Vaccination for female calves }\end{array}$} & Pox, foot and mouth disease (FMD) \\
\hline & \multicolumn{2}{|c|}{ Vaccination for female calves } & $\begin{array}{l}\text { Pox, foot and mouth disease (FMD, } \\
\text { brucellosis }\end{array}$ \\
\hline & \multicolumn{2}{|c|}{ Age of identification (days) } & $20.00 \pm 0.00$ \\
\hline & \multirow{7}{*}{$\begin{array}{l}\text { In last } \\
12 \\
\text { mounts }\end{array}$} & Number of calves was born & $29.90 \pm 5.00$ \\
\hline & & Number of lossed calf & $4.27 \pm 1.79$ \\
\hline & & The calf mortality (\%) & $11.44 \pm 2.05$ \\
\hline & & Disbudding & Yes $(90.00 \%)$, no $(10.00 \%)$ \\
\hline & & Disbudding methods & $\begin{array}{l}\text { Chemical }(6.67 \%) \text {, surgical }(50.00 \%) \text {, } \\
\text { hot-iron }(33.33 \%)\end{array}$ \\
\hline & & Calf age for disbudding(days) & $4.83 \pm 0.83$ \\
\hline & & Anesthesia for disbudding & Yes $(3.33 \%)$, no $(86.67 \%)$ \\
\hline
\end{tabular}

\section{DISCUSSION and CONCLUSION}

According to the results of this survey was conducted in dairy farms in Bayındır district of İzmir province, the materials and devices used in the construction of calf barns and pens were not harmful to calves and the properties with insulation, heating and ventilation of the calf barns were appropriate. The pen floors in the calf barns were flat, smooth and not slippery, which were favorable for avoiding falling of the calves (FAWC 2019b). In the majority of the visited farms, frequency of equipment disinfection and cleaninging of floors in the calf barns were insufficient, and the resting areas with plenty of bedding material were low (only $3.40 \%$ of the farms). But, bedding and cleaning in the calf barns and pens are critical to ensure well-being of the calf (EU 2009, Anonymous 2014, DEFRA 2000) and, this housing 
areas should be cleaned frequently and, feces or other contaminats should be removed frequently to minimize the odors and prevent the barns from attracting flies or rodents (Vasseur et al. 2010, Webster 2019). Especially in small and medium-sized dairy farms, bedding useage was not common and the ratio calf barns with dirty calf pens increased as the size of the enterprise increased. These results were evaluated as a risk for the health and welfare of calves. Thus, it is remarkable that the on-farm calf mortality were high (11.44\%). According to Ninomiya and Sato (2009), floor dirtiness and the small amount of bedding materials in calf pens causes to increase of calf's standing behavior which retain the calf from resting and increases the calf's stress, pain, and suffering. Supporting to this reserach findings, Camiloti et al. (2012) concluded that dairy calves prefer to dry bedding and showed reluctanance to lying on concrete floors and, then they argued that to access soft and dry bedding of growing calves is significant.

Another minimum welfare requirement for calves is that the calves should be able to perform their natural behaviors as much as possible and accommodated in an environments with minimal restriction (EU 2009, Anonymous 2014). In $6.67 \%$ of dairy farms, calves were housed only in individual pens majority of which were constructed using wood and metal. As legal minimum requirements for calf welfare, the width of any individual calf pens should be at least equal to the height of the calf at the withers, measured in the standing position, and the pen length should be at least equal to the body length of the calf (EU 2009, Anonymous 2014). Accordingly, width and lenght of the calf pens and barns were measured. Our finding on average individual pen width was $157 \mathrm{~cm}$ and this value were higher than the average cidago height (73-86 cm between birth and 8 weeks of age) reported by Doğan (2014) for Holstein calves. It has been argued that the measured length $(231 \mathrm{~cm})$ of the individual calf pens is also compatible with the minimum requirements because this value is longer than 1.1 times of the average Holstein calf body length (72-96 cm for 8-weeks old calves) (Doğan 2014). These results suggest that individual calf pens provide sufficient space for movement or grooming for calves, in line with the findings of Le Neindre (1993). The size of the dairy farm increased, the number of individual calf pen on the farm increased, but the average area of these individual calf pens decreased. Morever, the average duration of confinement of calves in individual pens was calculated as 86.11 days in this research and, it was not compiable with the minimum requirement that calves cannot be kept in individual pens after 8 weeks of age. The ratios of the farms that the calves were housed in group pens and, both types of housing were determinated were $63.33 \%$ and $30.00 \%$. The living area per animal was calculated as $4.33 \mathrm{~m}^{2}$ in the group pens and this value complies with the minimum requirements. This results showed that group calf pens provide the animals with wide space to move around and exercise. According to the minimum requirements for the protection of calves, the space allowance available to each calf should be at least equal to $1.5-1.8 \mathrm{~m}^{2}$ for each calves kept in group pens (EU 2009, Anonymous 2014). Group housing is reported to be more favorable for calf welfare for the reason it could provide social contact with other animals, play and exercise opportunities (Hänninen et al. 2005). But, there are conflicting reports of the impact of group housing on health, growth, or yields in calves (Le Neindre 1993, Hänninen et al. 2005, Doğan 2014).

Considering the legal minimum requirements for good feeding principle, it can be said that dairy farms in Izmir were generally compatible. All calves were fed at least twice a day with an appropriate diet (fibrous food, iron, etc.) adapted to their age, weight and behavioural and physiological needs and calves could access to the food at the same time when they kept in group pens with an automatic feeding system (EU 2009, Anonymous 2014, FAWC 2019b).

The calves were receiving their first colostrum meal within 6 hours immediately after birth and then they were fed with milk for 3 days. Feeding with milk and colostrum was carried out with bottle or bottle buckets and, it was thought that this may provide an opportunity for good human-animal interactions. These results show that the farms meet minimum welfare requirements for early calf feeding. It is especially important for calves to get enough colostrum in order to gain adequate immunity and to protected from diseases (EU 2009, Anonymous 2014). But, in one-third of the dairy farms $(36.70 \%$ of farms) cleanliness and functioning of the feeding systems were insufficient, and this was a risk that could adversely affect calves' access to food as well as to calf health and welfare.

Farmers' preference for weaning criteria was calf age however this may adversely affect calves(Vasseur et al. 2010). Starting to take solid foods before rumen development of calves consuming milk or liquid foods can pose risk to their health and well-being (Baldwin et al. 2004). So, Greenwood et al. (1997) reported that male and female calves should reach daily concentrate feed which is sufficient for weaning on different days. For avoid a stressful weaning and the absence of calf losses after weaning, a smooth transition from liquid food to solid food should be provided and calves should be weaned based on concentrate feed consumtion (Loberg et al. 2008). Supporting to this reports, Le Neindre (1993) stated that milk-only diets should be avoided, and it is necessary to provide calves with adequate roughage. 
The minimum criteria that dairy farms should comply in terms of good health principle were evaluated in the study. The all farmers declared that they inpects all housed calves at least twice a day, provides veterinary care and treatment to sick animals and vaccinate all calves regularly (DEFRA 2000, EU 2009, Anonymous 2014). Otherwise, there was no artificial lighting in calf barns in one quarter of farms and $90.00 \%$ of the farms did not have generator. It was evaluated that these farms could not comply to the minimum requirement related to at least 8 hours lighting per day (EU 2009, Anonymous 2014) in order to meet the behavioral and physiological needs of calves (Kiley-Worthington 1983, DEFRA 2000).

Neither castration nor tail docking were performed in the farms, but calves were disbudded in $90.00 \%$ of the farms and this painfull procedure were applied to calves without adequate anaesthesia in $86.67 \%$ of farms. Horn is an significant welfare problem in the management of dairy cattle herd (Winder et al. 2016), therefore, disbudding is widely accepted (Gottardo et al. 2011). But, according minimum requirements for calf welfare the painfull procedures like as disbudding can only be performed under conditions that cause minimal stress, pain and suffering (Anonymous 2014). Anesthesia should be used in this procedures, and should be given by the veterinarian (FAWC 2019b, Vasseur et al. 2010). On the other hand, Winder et al. (2016) mentioned that the use of appropriate pain-control procedures in this surgical procedures also positively influenced the consumer's view for the dairy industry. Disbudding can be carried out by cautery or application of a chemical paste but all procedures cause definite stress responses and calves suffer even if anesthesia is used (Stafford and Mellor 2011). The recommended age for disbudding is differs in a range from first week to 2 months of age ( Alsaaod et al. 2014, FAWC 2019a). The avarage disbudding age was 4.83 days in this study, and early disbudding of calves may have reduced the negative effect of the absence of anesthesia. So, age is as important factor for anestesia usage for the reason horn bud is free-floating in the skin until about 2 mounths of age (Gottardo et al. 2011, Alsaaot et al. 2014, FAWC 2019a). One of the positive welfare findings in the study was the absence of calf mouthpieces.

It is concluded that, dairy cattle farms in the Bayındır district of Izmir province have appropriate welfare conditions in terms of calf feeding, health care and daily inspection to meet the minimum requirements of calves designated in EU and National legislation. Although adequate indoor living space was provided for calves, there were some gaps for compliance of the farms with legal requirements for dairy calf welfare. The main gaps were to keeping of calves in individual pens for a long time, the shortcomings related to cleanliness, disinfection and bedding usage in barns and, to tying the calves widely. To raise awareness of animal welfare and, training of farmers on concept and legislation of animal welfare has been suggested as a strategic approach in order to increase dairy farms' compliance with calf welfare requirements.

\section{REFERENCES}

Alsaaod M, Doherr MG, Greber D, Steiner A. Experience with the delegation of anaesthesia for disbudding and castration to trained and certified livestock owners. BMC Veterinary Research. 2014; 10(1): 35.

Anonymous. Buzağıların Korunması ile İlgili Asgari Standartlara İlişkin Yönetmelik. (Official Gazette Date: 22 November 2014, No: 29183).

Anonymous. Süt Sektör Politika Belgesi 2018-2022. Tagem ArGe \& Innovasyon. 2018; Ankara.

Baldwin RLVI, McLeod KR, Klotz JL, Heitmann RN. Rumen development, intestinal growth and hepatic metabolism in the pre- and postweaning ruminant. J. Dairy Sci. 2004; 87:E55-E65.

Beam AL, Lombard JE, Kopral CA, Garber LP, Winter AL, Hicks JA, Schlater JL. Prevalence of failure of passive transfer of immunity in newborn heifer calves and associated management practices on US dairy operations. Journal of Dairy Science. 2009; 92(8):39733980 .

Berckmans D. Precision livestock farming technologies for welfare management in intensive livestock systems. Scientific and Technical Review of the Office International des Epizooties. 2014; 33(1):189-196.

Blanchard $\mathbf{O}$. The economic future of Europe. Journal of Economic Perspectives. 2004; 18(4):3-26.

Blokhuis HJ, Jones RB, Geers R, Miele M, Veissier I. Measuring and monitoring animal welfare: transparency in the food product quality chain. Animal Welfare-Potters Bar Then Wheathampstead. 2003; 12(4):445-456.

Camiloti TV, Fregonesi JA, Von Keyserlingk MAG, Weary DM. Effects of bedding quality on the lying behavior of dairy calves. Journal of Dairy Science. 2012; 95(6):33803383.

DEFRA. Guidance for Caring for beef cattle and dairy cows. 2000; UK., (Aviable at https://www.gov.uk/government/publications/code-ofrecommendations-for-the-welfare-of-livestockcattle/beef-cattle-and-dairy-cows-welfarerecommendations; Accessien date: 03.09, 2019).

Doğan Z. Siyah-alaca buzağılarda farklı sütten kesme yaşının büyüme performans1 üzerine etkileri. 2014;(Master's thesis, Adnan Menderes Üniversitesi).

EFSA (European Food Safety Authority). Shaping the future of food safety, together: proceedings of the 2nd EFSA Scientific Conference. Milan, Italy, 14-16 October. EFSA Journal. 2015; 13(10):1310-1317.

EU (European Union) Directives Council Directive 2008/119/EC of 18 December 2008 laying down minimum standards for the protection of calves. 2018; Official Journal of the European Union L 10/7, 15.1.2009.

FAWC. Disbudding and dehorning.2019a;Available at: http://www.fawc.org.uk/reports/dairycow/dcowr069.ht m.; Accessien date: 11.09, 2019). 
FAWC. Animal Welfare Guidelines for Darry Farmer. Farm Animal Welfare Advisory Council. The Department of Agricultural and Food, Ministry of Agriculture, Fisheries and Food. 2019b; UK. (Aviable at: http://www.fawac.ie/publications/animalwelfareguidelin es,Accessed 23.08, 2019).

Gottardo F, Nalon E, Contiero B, Normando S, Dalvit P, Cozzi G. The dehorning of dairy calves: practices and opinions of 639 farmers. Journal of Dairy Science. 2011; 94(11):5724-5734

Greenwood RH, Morrill JL, Titgemeyer EC. Using dry feed intake as a percentage of initial body weight as a weaning criterion. Journal of Dairy Science. 1997; 80: 2542-2546.

Hänninen L, De Passillé AM, Rushen J. The effect of flooring type and social grouping on the rest and growth of dairy calves. Applied Animal Behaviour Science. 2005; 91(3-4): 193-204.

Kiley-Worthington M. The behavior of confined calves raised for veal: Are these animals distressed?. International Journal for the Study of Animal Problems. 1983; 4(3), 198-213.

Le Neindre $\mathbf{P}$. Evaluating housing systems for veal calves. Journal of Animal Science. 1993; 71(5): 1345-1354.

Loberg JM, Hernandez CE, Thierfelder T, Jensen MB, Berg C, Lidfors L. Weaning and separation in two steps-A way to decrease stress in dairy calves suckled by foster cows. Applied Animal Behaviour Science. 2008; 111(3-4): 222-234.

Main DCJ, Mullan S, Atkinson C, Cooper M, Wrathall JHM, Blokhuis HJ. Best practice framework for animal welfare certification schemes. Trends in Food Science \& Technology. 2014; 37(2): 127-136.

Miller CJ, Howden SM, Jones R N. Preparing Australian Agriculture, Forestry and Fisheries For The Future. In: Intensive Livestock İndustries Adapting Agriculture To Climate Change, Ed; Stokes C, Howden M, e-book. Csiropublishing, USA.2010; pp. 171-185.

Ninomiya S, Sato S. Effects of 'Five freedoms' environmental enrichment on the welfare of calves reared indoors. Animal Science Journal. 2009; 80(3):347-351.

OIE (World Organisation for Animal Health). Chapter 7.1. Introduction to the recommendations for animal welfare, Article 7.1.4. In Terrestrial Animal Health Code, 21 st Ed. 2012, OIE, Paris, 305-306. Available https://www.oie.int/en/standard-setting/terrestrialcode/access-

online $/$ ?htmfile $=$ chapitre_aw_introduction.htm; Accessien date: 17.9.2019).

Smil V. Worldwide transformation of diets, burdens of meat production and opportunities for novel food proteins. Enzyme and Microbial Technology. 2002; 30(3):305-311.

Stafford KJ, Mellor DJ. Addressing the pain associated with disbudding and dehorning in cattle. Applied Animal Behaviour Science. 2011; 135(3):226-231.

Vasseur E, Borderas F, Cue RI, Lefebvre D, Pellerin D, Rushen J, Wade KM, Passille AM. A survey of dairy calf management practices in Canada that affect animal welfare. Journal of Dairy Science. 2010; 93(3):1307-1316.

Webster J. Calf husbandry, Health and Welfare. 1th Ed. CRC Press. UK.2019; pp.37-204.

Welfare Quality ${ }^{\circledR 2009}$. Welfare Quality ${ }^{\circledR}$ assessment protocol for cattle. Welfare Quality ${ }^{\circledR}$ Consortium, Lelystad, 2009, The Netherlands.
Winder CB, LeBlanc SJ, Haley DB, Lissemore KD, Godkin MA, Duffield TF. Practices for the disbudding and dehorning of dairy calves by veterinarians and dairy producers in Ontario. Canada. Journal of Dairy Science. 2016; 99(12):10161-10173. 